\title{
The Problem Faced by Syrian Refugee Students in the General Education Process and Especially in Mathematics Education
}

Türkiye'de Bulunan Suriyeli Göçmen Öğrencilerin Genel Eğitim-Öğretim Sürecinde ve Özelde Matematik Eğitiminde Yaşadıkları Zorluklar

\author{
Çiğdem İnci Kuzu ${ }^{1 *(D)}$, Mounzer Mlehan Aljadaan² \\ ${ }^{1}$ Karabuk University, Faculty of Science, Department of Mathematics, Karabuk, Turkey \\ ${ }^{2}$ Karabuk University, Graduate School of Education, Karabuk, Turkey
}

\begin{abstract}
This research is aimed to determine the general problems that the students encounter in the education-teaching environment and especially their difficulties in mathematics education, in line with the opinions of the Syrian refugee students studying in Sanliurfa and the teachers who teach mathematics courses. The case study approach, one of the qualitative research designs, was used in the research. The research participants are mathematics teachers who teach Syrian refugee students in Şanliurfa in the 2020-2021 academic year, Syrian refugee students have been educated in these schools, and a national education inspector have been working in this province. Participants were formed according to easily accessible situation sampling, one of the purposeful sampling methods. The eight of the participants are students, the four of them are mathematics teachers, and one is a national education inspector. The data of the research were collected by semi-structured interview technique and analysed in accordance with the content analysis technique. In the analysis of the data, the descriptive analysis technique was used. According to the research findings, it has been determined that solving Syrian refugee students' educational problems, especially the language problem, should be resolved. The appropriate education program should be planned. The course hours should be arranged, the right resources should be prepared and used for mathematics education, and the necessary psychological support should be provided to the refugee students. It is among the results that the mathematics teachers, who stated that they tried to exhibit an attitude in the classroom environment in a way that would enable students to integrate with each other, had consistent experiences. In addition, according to the findings obtained from the opinions of mathematics teachers, it was determined that refugee students could not understand mathematical problems correctly. It is recommended that curricula should be planned in a suitable way for refugee children and that this issue should be arranged in a long-term manner.
\end{abstract}

Keywords: Syrian refugee students, Educational problems, Mathematics education, Teacher opinions.
$\ddot{O ̈ z}$

Bu araştırmanın amacı Şanlıurfa ilinde öğrenim görmekte olan Suriyeli mülteci öğrenciler ve bu öğrencilerin matematik derslerini yürüten öğretmenlerin görüşleri doğrultusunda öğrencilerin eğitim-öğretim ortamlarında karşılaştıkları genel sorunları ve özelinde matematik eğitiminde yaşadıkları sıkıntıları belirlemektir. Araştırmada nitel araştırma yaklaşımı kullanılmıştır. Araştırmanın katılımcılarını 20202021 eğitim öğretim yılında Şanlıurfa ilinde Suriyeli mülteci öğrencilerin dersine giren matematik öğretmenleri, bu okullarda öğrenim gören Suriyeli mülteci öğrenciler ve bu ilde görev yapmakta olan bir milli eğitim müfettişi oluşturmaktadır. Katılımcılar amaçlı örnekleme yöntemlerinden kolay ulaşlabilir durum örneklemesine göre oluşturulmuştur. Katılımcıların sekizi öğrenci, dördü matematik öğretmeni ve biri milli eğitim müfettişidir. Araştırmanın verileri yarı yapılandırılmış görüşme tekniği ile toplanmış ve içerik analizi tekniğine uygun olarak çözümlenmiştir. Araştırmanın sonucundan elde edilen bulgularına göre; Suriyeli mülteci öğrencilerin eğitim sorunlarının halledilebilmesi için özellikle dil probleminin çözümlenmesi, uygun eğitim programının planlanması, ders saatlerinin düzenlenmesi, matematik eğitimi adına doğru kaynakların hazırlanıp kullanılması, matematik terimler sözlüğüne ihtiyaç olması, mülteci öğrencilere gerekli psikolojik desteğin sağlanması gerektiği belirlenmiştir. Sınıf ortamında öğrencilerin birbirleri ile kaynaşmalarını sağlayacak şekilde tavır sergilemeye çalıştıklarını ifade eden matematik öğretmenlerinin, tutarlı deneyimlere sahip oldukları araştırma sonuçları arasındadır. Bunun yanında matematik öğretmeni görüşlerinden elde edilen bulgulara göre mülteci öğrencilerin matematiksel problemleri doğru anlayamadıkları belirlenmiştir. Öğretim programlarının mülteci çocuklara uygun olacak şekilde planlanması, bu konunun uzun vadeli olarak düzenlenmesi önerilmektedir.

Anahtar Kelimeler: Suriyeli mülteci öğrenciler, Eğitim sorunları, Matematik eğitimi, Öğretmen görüşleri. 


\section{Introduction}

People or societies may feel the need to change their place of residence for various reasons. In this respect, when the definition of migration is considered, migration is the act of individuals or communities leaving their residence for political, social, or economic reasons and going to another settlement or another country within their country (Turkish Language Society, 2021). Changing the country where a person lives in immigration for asylum may be due to political, religious, or ethnic pressures. For this reason, because of political, ethnic, or religious discrimination and conflicts, many people can migrate inside or outside the country (Çiçekli, 2009).

The fleeing Syrians from the civil war that broke out in Syria in 2011 started to take shelter in neighbouring countries. Due to its geographical location, Turkey is among the countries most affected by the Syrian war. The first convoy arrived in Turkey in 2011. The number of refugees who came after this date, starting with the numbers in the thousand and exceeding 3.5 million (Ministry of Interior Migration Administration, 2020), and the Syrians entering to Turkey have been placed under temporary protection (Özdemir, 2017). In these ten years, when the unresolved civil war made it impossible to return, the integration of Syrian refugees into Turkey has become a necessity in terms of social order and coexistence. Although the most critical problems of refugees who took refuge in another country with migration are work, education, and economic support, people become dependent on social assistance due to the wrong policies (Feuerherm, 2013).

Children have been most affected by these migrations, and in this respect, education is the most crucial topic for the integration of young Syrian refugees. Refugee children who cannot benefit from the right to go to school are at greater risk of abuse and maltreatment, show more post-traumatic stress disorder symptoms, and fail to complete their physical and psychological development (Erdem, 2017). Refugee children who cannot receive education cause child labour and early marriage. Young people who are not given educational opportunities can be dragged into radical groups. (Watkins \& Zyck, 2014). For all these reasons, it is necessary to ensure refugee children's access to education and eliminate the reasons that hinder the education process of these children. It is thought that this research is also essential in terms of reintegrating refugee children into social life. The educational barriers of Syrian children and the solutions offered by teachers are crucial in the research. Gencer (2017) classified the educational problems of refugee students as financial problems, access and participation problems in education, teacher problems, language problems, lack of coordination, curriculum and teaching materials, physical infrastructure problems, poverty, social acceptance, and adaptation problems.

The first education policies created in Turkey in 2012 for the education of Syrian children of educational age were formed on the expectation that Syrians would return to their countries quickly. In this direction, the first action was opening temporary education centres in the camps where the Syrians are located. In the ongoing process, the civil war in Syria has escalated, and the number of refugees coming to Turkey has increased. The Ministry of National Education started to seek institutional solutions for the education of Syrian children for the first time in 2013. With the circular numbered 2014/21, the education rights of Syrian refugee students were guaranteed to a certain standard. With this circular, it was stated that the temporary education centers aim to ensure that the war victims can continue their education and to prevent the loss of time that may occur when they return to Syria or want to continue their education in Turkey. In addition, it has been stated that the ministry will create weekly course schedules and curricula to ensure unity in these educational activities (Coşkun \& Emin, 2016).

The fact that refugee children in Turkey receive education in public schools has increased the responsibilities of teachers working in these schools. These responsibilities include psychological support, guiding their adaptation to the social environment, and communication with their peers. (Başaran Demir, 2020). In addition, teachers who want to guide students may face language problems. Along with the language problem, it can be challenging to cope with the low academic level of the students (Miller, 2009). The classroom environment is 
of great importance for these students. The methods were applied in the education process, the materials were used, and the assessment and evaluation processes should be planned to include refugee students. In this process, teachers rely on their teaching understanding to approach students and classroom management and shape their teaching accordingly. However, this trust of teachers in their individual experiences of guidance can be a problem when working with students from groups they have little experience and knowledge of, such as recent refugee students (Roxas, 2010).

There have been many studies investigating the educational problems of refugee children especially in recent years in Turkey, (Tuncay, 2021; Cırıt Karaağaç \& Güvenç, 2019; Jafari et al., 2018; Erdem, 2017; Erden, 2013).

Erdem (2017) investigated the instructional problems experienced by teachers in his study with classroom teachers with refugee students in his classroom. Cırıt Karaağaç and Güvenç (2019) investigated the educational problems of students in their study with students attending public primary schools in Turkey. Studies with teachers and refugee students were generally carried out with quantitative and qualitative methods to get opinions on the determination of problems. Similarly, in this study, the problems and discourses experienced by teachers and students during the education process were tried to be revealed. In addition, it can be stated that mathematics, which we encounter throughout our education life, and which takes place in almost every aspect of education life and daily life, starting from the pre-school period, has an important place in our lives when it is considered that it is a universal language. In addition to the importance of mathematics, another striking point is that mathematics lessons are seen as a difficult lesson to be learned by students in school life (İnci Kuzu, 2021; Özyıldırım Gümüş et al., 2015). In this context, the research aims to reveal the thoughts of the mathematics teachers who can best see the problems that Syrian students experience in the educationteaching process and especially in mathematics learning and what solutions they come up with regarding the problems experienced. Within the scope of the research, it is aimed to present the problems faced by the mathematics teachers and refugee students in 3 different schools where Syrian students legally registered in Şanliurfa are studying and offering solutions to these problems.

The problem sentence of this study was "What are the difficulties faced by Syrian migrant students in Turkey in the general education-teaching process and in learning mathematics in particular?". In order to find an answer to the question, the opinions of Syrian refugee students and their mathematics teachers were consulted.

\section{Method}

This study, it is aimed to obtain data on the educational status of the province of Şanliurfa, where the number of refugees is very high, based on the thoughts and experiences of the refugee students and teachers. A qualitative research method was used in the research. Qualitative research is sensitive to the natural environment, has a holistic understanding, reveals the perceptions of the participants, and the researcher also has a participant role (Yıldırım \& Şimşek, 2013). Since the study is based on the experiences of refugee students and teachers, it is phenomenological research. The main goal of the phenomenological study is to determine the individual's perception of his/her experiences (Patton, 1990). The research was carried out in order to reveal how the teachers make sense of the education of refugee children and how they try to reach and support them, as well as what kind of problems refugee students encounter in the education they receive in Turkey. In this respect, it is in the category of descriptive phenomenological research.

\subsection{Participants}

The research participants consisted of mathematics teachers working in schools where refugee students are concentrated in Şanlıurfa in the 2020-2021 academic year and refugee students studying in these schools. Although it was not encountered in the teachers participating in our research, teachers can graduate from different faculties (e.g., Education, Science, Literature, etc.) in Turkey. Because of this situation, there are 
differences in their experiences. In this context, the faculties graduated from were also collected as data. In addition, the opinions of a national education inspector who worked in the Ministry of National Education for 19 years and who has been working in the province of Şanliurfa for the last ten years were included in the study. Participants in the study were formed according to "convenience sampling," one of the purposeful sampling methods. This sampling method adds speed and applicability to the research (Y1ldırım \& Şimşek, 2013). The demographic characteristics of the refugee students participating in the research were given in Table 1, and the demographic characteristics of the teachers participating in the research were given in Table 2 .

Table 1

Demographic characteristics of students

\begin{tabular}{lllll}
\hline Students & Gender & Age & Grade & $\begin{array}{l}\text { Education } \\
\text { time (year) }\end{array}$ \\
\hline K1 & Male & 16 & 10 & 3 \\
K2 & Male & 14 & 9 & 3 \\
K3 & Male & 15 & 9 & 3 \\
K4 & Male & 16 & 10 & 3 \\
K5 & Male & 15 & 9 & 4 \\
K6 & Female & 16 & 10 & 6 \\
K7 & Female & 15 & 9 & 4 \\
K8 & Female & 16 & 10 & 5 \\
\hline
\end{tabular}

Four of the refugee students in the research were studying in the 9th grade, and five were in the 10th grade. In addition, it was determined that four students received education in Turkey for three years, two for four years, one for five years, and one for six years. More than half $(n=5)$ are male. The average age is 15 .

Table 2

Demographic characteristics of the educator staff

\begin{tabular}{lllllll}
\hline Educator & Situation & Gender & Seniority & $\begin{array}{l}\text { Working } \\
\text { experience with } \\
\text { refugee students }\end{array}$ & Branch & $\begin{array}{l}\text { Education } \\
\text { Background }\end{array}$ \\
\hline M1 & Inspector & Male & 19 & 8 & Biology & Faculty of Science \\
M2 & Teacher & Male & 9 & 3 & Mathematics & Faculty of Education \\
M3 & Teacher & Male & 12 & 2 & Mathematics & Faculty of Education \\
M4 & Teacher & Male & 16 & 5 & Mathematics & Faculty of Education \\
M5 & Teacher & Female & 7 & 3 & Mathematics & Faculty of Education \\
\hline
\end{tabular}

The average seniority of the teachers participating in the research is 11 years. It is only one person with less than ten years of seniority. More than half $(n=3)$ are male. All of the mathematics teachers have previous experience in teaching refugee students. 


\subsection{Data Collection Tool}

Qualitative data were collected in the study. Qualitative data were obtained from semi-structured interviews with the participants. Semi-structured interviews are organized around predetermined open-ended questions, and other questions that arise during the interview are added (Yıldırım \& Şimşek, 2013). In order to collect the data of the research, the "Ideas of Syrian immigrant students about studying in Şanliurfa form " and "teachers" thoughts about Syrian immigrant students form" prepared by the researchers were used. These interview forms consist of two parts: demographic characteristics and interview questions. The interview questions were prepared according to the literature (Özyıldırım Gümüş et al., 2015; Kultas, 2017, Başaran Demir, 2020; Erdem, 2017; Kayac1k, 2020) on the problems of immigrant students in the education- teaching environment, and the aims of the research. While there were nine open-ended questions in the form prepared for students, four questions were prepared for teachers. In addition, in line with the answers given by the participants during the interviews, probe questions were also asked the participants. The prepared questions were transformed into a form where the research problem and purpose were expressed and presented to the field experts. A pilot interview was conducted with one teacher and one student to test the clarity of the questions on which necessary corrections were made in line with the opinions received.

\subsection{Data Collection, Analysis, and Interpretation}

Necessary official permissions were obtained in order to collect the data. Interviews were held in the fall semester of the 2020-2021 academic year, with teachers at their schools, in empty classrooms, with refugee students in their gardens due to the Covid-19 pandemic. Since the researcher who conducted the interview was a graduate student of Syrian nationality, he communicated well with refugee students and their families. Before starting the interview, it was stated that a voice recorder would be used to listen to the interviews again, to analyze them without data loss, and to make direct quotations, and permission was obtained from the participants. It has been explained that the research is based on confidentiality, that identity information will be kept confidential, and that the data obtained will be used only for scientific purposes. The interviews lasted an average of 30-40 minutes. In the interviews, the participants were asked whether there was any other subject they wanted to talk about apart from the questions, and the interviews continued in this direction. This was very helpful as it helped to understand the interviewees. It was observed that teachers and refugee students were willing to express their views and experiences. In analyzing the data obtained from the interviews, the records were first transcribed, and the interviews recorded in Arabic were translated. The other researcher examined the data recorded with the voice recorder in terms of coding and categorization, ensuring consistency. The data were analyzed by the content analysis technique. Each interview was analyzed within its framework of meaning. Then, each question was examined separately, and code labels were assigned to the texts. The findings are presented as a requirement of qualitative research, blended with the comments and evaluations of the researcher.

\section{Results}

This study is aimed to examine the opinions of refugee students studying in Şanliurfa and mathematics teachers working in schools where refugee students are concentrated.

\subsection{Opinions of Refugee Students on the Education Process}

The opinions of the Syrian refugee students interviewed within the scope of the study on the problems they encounter in their education processes and mathematics learning were examined under five main headings. These are education program, education process, psychological traumas, instructional materials, mathematics education. The codes were created according to the data obtained from the teachers. 
The biggest problem faced by the Syrian refugee students interviewed in public schools was determined not to speak Turkish properly and not understand it correctly. Stating that the language barrier caused the students not to communicate with the teachers, $\mathrm{K} 3$ expressed the situation as "I do not understand the lessons well, and I cannot explain and ask the subject that I do not understand because I do not know Turkish well." As a result of this situation, it has been observed that refugee students feel like they are excluded. Another situation that emerged under the title of language was determined as the inability of refugee students to understand the concepts correctly. This situation causes students to drop out of the course after a while. Of the refugee students interviewed, $2(\mathrm{n}=2)$ stated that they did not have much trouble communicating with their teachers, and $6(\mathrm{n}=6)$ stated that they had much trouble. Five $(n=5)$ of the refugee students who participated in the research stated that "Our Turkish is not sufficient," and $3(n=3)$ stated that "I do not find Turkish courses sufficient for university education." Regarding the problem of the fact that the staff of educational institutions does not consist of teachers in their main branch, refugee students $\mathrm{K} 5$ said that "As it is difficult to create staff from the faculty of education, engineers, lawyers, economists, and some high school diploma holders work even though they are not experts in mathematics teaching. Teachers who enter our classes in this way do not care much about us.". This statement shows that due to the inadequacies of the teaching staff, people from occupational groups who are not experts in their fields or who are not educators, and their pedagogical deficiencies negatively affect refugee students. In addition, half of the students $(n=4)$ stated that the educators blamed them as the sole reason for failure. It is thought that the counsellors working at the school remain passive in communicating such problems to the management, and therefore, students have low motivation. K2's views on this situation were "Since our relationship with the administration is provided through consultants, a healthy flow of information cannot be ensured, the school administration's lack of direct contact with us causes our problems to grow, and we are alienated from the school." was in the form. Table 3 has been prepared to see the sub-themes and codes that explain the phenomenon.

Seven students $(\mathrm{n}=7)$ stated that the weekly course hours are insufficient for Turkish and mathematics courses. Only one student $(n=1)$ stated that Turkish lesson hours are too long. On this subject, K8 said, "My friends like me, and I can understand a question when it is asked more than once, and we fall behind. Sometimes we deal with one question for the whole lesson, and our teachers say that the topics will not catch up. It would be better if the lesson hours were increased." expressed an opinion. The student emphasized that they were behind in the subjects. This situation shows that refugee students have a fear of failure.

Six of the refugee students $(n=6)$ who participated in the study stated that the education program was not at a level suitable for the age and abilities of the refugee students, and they could not adapt because the education program in Syria and Turkey was different. The curriculum in temporary schools with refugee students in Turkey focuses on abstract thinking and mathematics is similar to that of European Union countries. However, a problem has been encountered in Turkey, such as not evaluating the education level of refugee students and placing them in the appropriate class. 4 students $(n=4)$ stated that they had difficulty adapting due to the curricular differences between the two countries. Two students $(n=2)$ stated that they thought the level determination process in Turkey was not correct. Regarding this subject, the Statement of K1 was, "I have a problem in adapting to school because I could not be placed in a class suitable for my level." Level assessment is based on the student's age and height in most schools. Accordingly, adaptation problems have arisen. It has been observed that the students, who stated that the education program is well above their level, are not very hopeful about the future due to the anxiety of the education system. In addition to these, the language problem creates another negative situation.

Six refugee students $(n=6)$ stated that they could not find suitable sourcebooks or supplementary books for them since they started their education in Turkey, did not understand most of the terms, and had much trouble, especially in the first years of their arrival in Turkey. They added that the teachers sometimes used materials 
such as maps and microscopes in the lesson and attracted more attention. K6's statement was, "There is no example suitable for our culture in the books anyway. I do not find the books very suitable for us."

Table 3

Codes and categories for the problems faced by Syrian refugee students in the education process

\begin{tabular}{|c|c|c|}
\hline Codes & Main problems voiced by Syrian refugee students & $\mathrm{f}$ \\
\hline \multirow{4}{*}{$\begin{array}{l}\text { Education-teaching } \\
\text { process }\end{array}$} & Language Barrier (Inability to use Turkish language adequately) & 8 \\
\hline & $\begin{array}{l}\text { The fact that the staff of educational institutions does not consist of } \\
\text { teachers in their main branch. }\end{array}$ & 3 \\
\hline & $\begin{array}{l}\text { Difficulty in accessing school management for solving problems at } \\
\text { school }\end{array}$ & 2 \\
\hline & Insufficient lecture hours & 7 \\
\hline \multirow[t]{2}{*}{ Educational program } & $\begin{array}{l}\text { The education program is not suitable for the refugee student age } \\
\text { and abilities }\end{array}$ & 6 \\
\hline & Syrian-Turkish curricular differences & 6 \\
\hline Teaching Materials & Lack of Turkish-Arabic resources & 6 \\
\hline Psychological traumas & Psychological traumas make it challenging to adapt to classes & 7 \\
\hline \multirow{4}{*}{ Mathematics Education } & $\begin{array}{l}\text { Inadequacy of terminology dictionaries to facilitate mathematics } \\
\text { education }\end{array}$ & 4 \\
\hline & Inadequate class hours for mathematics learning & 5 \\
\hline & $\begin{array}{l}\text { Not understanding the problems, setting up wrong or incomplete } \\
\text { equations }\end{array}$ & 7 \\
\hline & More comprehensive mathematics curriculum in Turkey & 3 \\
\hline
\end{tabular}

Refugee students who participated in the study stated that they experienced severe traumas such as dropping out of school due to the war in Syria, displacement and migration, confusion, and focusing problems. Three students stated their failure to the effect of the trauma they experienced due to the war, and two students stated that they could not adapt to immigration. Two students stated that returning to school after a break from school was a problem, and one student stated that their school success was low due to distraction. K7 stated that "I had to struggle with the difficulties of re-adapting after taking a break from school." P4 stated that "I cannot achieve success in education because I am under the influence of the trauma I experienced due to the war."

One of the main facts that the research focuses on was the problems that refugee students' problems in mathematics education. Five $(n=5)$ of the refugee students who participated in the study stated that they are used to the textbooks in their own countries and the questions in mathematics lessons suitable for their own culture and lifestyle. They stated that the mathematics curriculum and questions in schools in Turkey are in a different style, and they need education, and this situation brings their shortcomings to light. They stated that it was on their face. In the mathematics lesson, $5(n=5)$ students stated that they had difficulties in all subjects, and three students $(n=3)$ stated that they were doubly confused, especially in problem questions. They first tried to understand the problem, and then they tried to solve it. Two refugee students stated that they had problems with the basic mathematics sourcebook, and they could not get it because their financial situation was not available.

Four students stated that they want to benefit from the Turkish-Arabic bilingual basic mathematics dictionaries at school and home. However, they have difficulties because there are not enough variety and quality 
mathematical terms in the market, and they sometimes use the educational information network (EBA). All of the students participating in the research think that weekly mathematics lesson hours are insufficient and makeup lessons should be given. Due to these negative situations, it is seen that they have turned into beliefs that they will never be able to take the mathematics course, which they think is problematic. The $\mathrm{K} 7$ coded student explained the difficulties they experienced in their mathematics lessons: "Mathematics is essential for us because it is our most important lesson. We cannot succeed in any exam if we cannot do it. We have to compete with the Turkish students here. The same questions are asked in the exam, and the one who does mathematics well wins. They start solving problems right away, but we try to understand first, so the time is not enough, and sometimes we get it wrong and make mistakes. Make-up lessons should be made for us or the mathematics course hours should be increased". K2's thoughts were, "I could not understand the math textbooks very well, and sometimes I use EBA. There are no questions that we are used to. I feel alien. I used to love mathematics, but I cannot do it here".

\subsection{Opinions of Mathematics Teachers towards Refugee Students}

It has been tried to determine what kind of problems mathematics teachers face in classrooms where refugee students are concentrated. The answers show that the biggest problem of teachers, in general, is language and communication. The mathematics teachers' opinions on the problems they encounter in their education processes and mathematics learning were examined under ten main headings. These are language problems, cultural differences, psychological traumas, resource problems, parent communication problems, peer negative attitudes, inadequate lesson hours, absenteeism problems, lack of lesson hours, lack of basic mathematics, and assessment and evaluation problems. Table 4 has been prepared to see the codes that explain the phenomenon.

The mathematics teachers $(n=4)$ who participated in the research mentioned the language problem firstly. They stated that this problem poses a more significant problem in primary education. Children who come to Turkey at younger ages learn languages more quickly. The process becomes more difficult as the age gets older. On this subject, K6 said, "Syrian students must receive an education in terms of language and behaviour before being admitted to classes. The adaptation period of students who come to the country after a certain age is longer. Teachers working in primary schools say that they are more troubled in this regard." he said. It has been determined that refugee students feel excluded and inadequate in the classroom environment since they do not fully understand the language in mathematics lessons, do not understand what the teacher says, misunderstand, and do not understand the terms. Two of the teachers who participated in the research think that the participation of Syrian students in Mathematics lessons is better than other lessons. M5's opinion on this subject is that "They understand the mathematics lesson better, but they have difficulty in understanding the questions." M2 said, "Since the mathematics course is a universal language, Syrian students are better off than verbal courses." They stated that the participation of refugee students in mathematics is better than in other courses. K4 of the three teachers who attributed the children's inability to learn Turkish to families said, "Families should learn Turkish first. For this, Turkish television channels should be processed and Turkish should be spoken at home".

K1 "Turkish course should be given to Syrian students, it should not be optional, it should be compulsory, and it should be given before they start school." K2 said, "The majority of the students grew up here. However, since their families speak their native language, they cannot speak Turkish well. Although we can communicate with students, we cannot talk to parents at all. We cannot convey the problems of the students to their families. Three teachers claimed that the mathematics textbooks were not suitable for the students' level. K2's statement on this subject said, "When we teach in classrooms with a large number of refugee students, we cannot find a proper resource for these students. Although it is a resource, children do not have the opportunity to buy extra books anyway. Both students and we are struggling. They keep saying they do not understand, and they want 
a make-up lesson for themselves". The teachers said that while the attitudes of Turkish students in the classroom towards Syrian students were much more prejudiced and exclusionary in the early periods, it evolved into friendship over time with the teachers' efforts to develop positive attitudes, but the families were still prejudiced. P4 on this subject said, "It is not like in the first years. Students are now accepting refugee students. However, there is still prejudice in families, especially regarding cleaning. There is an attitude that refugee students will infect disease. Furthermore, kids are just in their teens. Turkish families treat their children as if they will join an organization if they make friends with refugees who are in poor financial situation." Another problem expressed by the teachers is the absenteeism of refugee students due to deficiencies in the legislation. Teachers $(n=2)$, who stated that there was no sanction in this regard, stated that refugee students did not come to school for a long time by using this situation. However, the teachers also stated that they did not know where the students were during this period, and they were worried that they might have participated in any event.

\section{Table 4}

Codes and frequencies of the problems faced by mathematics teachers in the education-teaching process

\begin{tabular}{ll}
\hline Codes & f \\
\hline Language problem & 4 \\
Cultural differences & 4 \\
Psychological traumas & 4 \\
Lack of resources & 3 \\
Parent communication problem & 3 \\
The negative attitude of peers & 3 \\
absenteeism problem & 2 \\
Lack of lesson hours & 2 \\
Lack of basic math knowledge & 3 \\
Measurement and evaluation problem & 3 \\
Teachers' lack of experience & 4 \\
\hline
\end{tabular}

Mathematics teachers stated that the basic mathematics knowledge level of refugee students varies according to whether they start education in Syria or not. On this subject, K4 stated that "The basics of a few students were excellent. They solve the operation questions very well. They received a good education in their country". In contrast, K1 stated that their basic mathematical knowledge was feeble and said, "They do not know anything. It is like they did not see the math. For ten years, these students could not establish order and travelled from city to city. They cannot even read properly, let alone mathematics."

Another problem expressed by three $(n=3)$ of the teachers participating in the research was determined as measurement and evaluation. Teachers stated that it is unfair to mention Turkish students and refugee students with the same exam and apply multiple-choice tests. K3 expressed his thoughts on the subject, "It is not clear how we will evaluate refugee students, and if we do, how we will do it. There is no legislation on this subject. This situation poses a problem for both students and us. I give students multiple-choice exams so that individuals have a chance to do it." expressed as. Finally, all of the interviewed teachers emphasized that they had attended the courses of refugee students before, and that experience was of great importance in this regard. $\mathrm{K} 1$ 's views on this subject are as follows: "This is the 5th year that I have attended refugee students' classes, and I am very experienced, consistent, and knowledgeable compared to my first year. Over time, my perspective on these students has changed, but unfortunately, most teachers are inexperienced in this regard. 
This situation wears out both the student and the teacher. I think it would be beneficial to plan accordingly when training teachers."

Teachers were asked to make suggestions regarding the identified problems. The suggestions of the four mathematics teachers included in the study regarding the education processes of refugee students are presented in Table 5 .

Table 5

Recommendations of mathematics teachers regarding problems encountered by refugee students

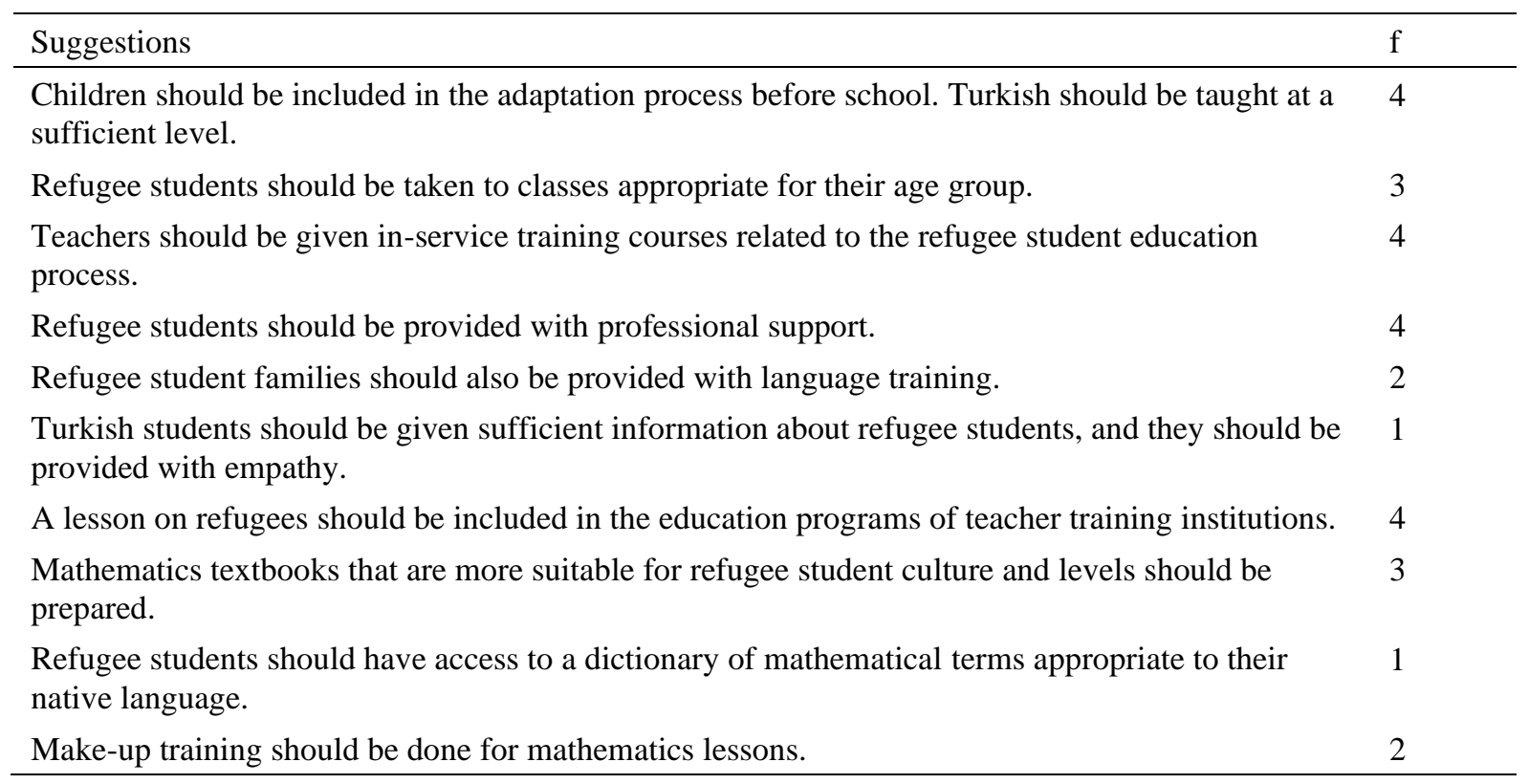

\subsection{Views of the National Education Inspector on Refugee Students}

Within the scope of the research, the themes obtained from the interview with a national education inspector in order to benefit from the experiences of an instructor who has been a manager in this region for many years and dealt with the problems of students and teachers (Table 6) and statements related to these themes were given below.

"1-It is known that approximately 500 thousand Syrian refugees live in Şanliurfa and disperse to all its districts. Approximately 100 thousand refugee students are studying in pre-school, primary, secondary, and high schools. Some of these students study in camps and schools where Syrian teachers work, and most of them study in official educational institutions of the Republic of Turkey,

2- Generally, the most significant and fundamental problem is the integration problem,

3-The other and major problem that creates this problem is the language and communication problem,

4- The majority of refugee students do not have a father or mother, and many students live as orphans,

5-Refugee students are faced with constant exclusion due to the psychological problems of children who have experienced war with language, communication, social, cultural, and economic, 
6- Students, who cannot learn Turkish enough, have communication problems with teachers and students, which negatively affects their success in their classes,

7- Especially, students who have language and communication problems are unsuccessful in the first, second, third, and later grades of primary school, students who solve the language problem in a short time are more successful, and they compete with our students,

8- With the first years when Syrian refugee students came to our country, and at the end of the last ten years, the problem of adaptation in both families and students has been overcome to a large extent. It has been observed that the problems and complaints of our teachers and immigrant students have also decreased considerably, and it has been understood that the unity of Syrian citizens and students at the point of faith, with the people of our country, has a great contribution to the adaptation in a short time,

9-As a result of our state, civil and social associations, and our citizens' understanding of benevolence due to their beliefs and cultures, thanks to the social and economic assistance they provide to refugee families, it is understood that the problem of adaptation with Syrian citizens and students, with whom we have lived for about 4 centuries, has been overcome to a large extent. They can learn our language very quickly,

10-The war syndrome and the adaptation problem experienced by Syrian citizens and students have been overcome mainly due to the excellent tolerance and benevolence of our State and Nation. The adaptation and success of our refugee students have also been noticed in a positive way that cannot be compared to 10 years ago. In general, all our refugee students continue their education in the official education institutions of the state. In the classrooms, they are with our students, with fewer adaptation problems." (İnspector)

\section{Table 6}

Problem themes obtained from national education inspector opinion

\begin{tabular}{ll}
\hline Theme & Codes \\
\hline \multirow{2}{*}{ Socio-cultural problems } & Integration problem \\
& $\begin{array}{l}\text { Language problem } \\
\text { Cultural alienation }\end{array}$ \\
Familial problems & Parents passed away \\
Cognitive problems & Language problem \\
& Parent who died in war \\
Psychological problems & War syndrome \\
& Feeling alien \\
& Security concern \\
\hline
\end{tabular}

The interviews with the national education inspector determined that the most significant problems of refugee students were language and psychological problems caused by war. It is also among the findings that the adaptation problems of Syrian refugee students decrease over time.

\section{Discussion and Conclusion}

In the light of the findings obtained from the opinions of refugee students, mathematics teachers, and a national education inspector participating in the research, it has been determined that refugee students struggle with language, psychological problems, and family-related problems. One of the most critical reasons Syrian students cannot integrate and adapt with Turkish students is language problems. According to the opinions of 
the teachers obtained from the study, the application of combining them in a system that forces the student to learn Turkish in the first year and to understand the lessons quickly results in Syrian students frequently failing due to difficulties in understanding Turkish, reading and writing, and falling behind their peers. It is easy for young people who learn Turkish at a pre-school/early age to overcome the language barrier. Therefore, integration and adaptation processes are more trouble-free and successful than students older than themselves, especially those who start their education with Arabic. When the literature is examined, many study results are similar (Kaştan, 2015; Perşembe, 2010).

In this study, there are facts that the economic conditions of refugee students are not very pleasant, they do not have similar conditions with other students, and their advantages are few. In this context, it shows the necessity of planning studies on improving the conditions of refugee students, especially language, psychology, and family-related conditions. In the study conducted by Ayy1ldz in 2011, it was stated that Syria is the country most prone to learning Turkish and that these students learn Turkish more easily. Since Syrian students learn Turkish more quickly than other international students, students who receive Turkish education can participate more actively in the education process (Ayy1d1z, 2011).

This study determined that teachers who had the opportunity to attend the lessons of children of different nationalities in the teaching profession before expressed their problems less. With this study, Erden (2013) and Başaran Demir (2020) reported that the teachers in the schools where refugee students study do not have enough formation to overcome the problems. On the other hand, they stated that if the teachers had experience teaching refugee students before, the problems experienced decreased. The ability to adapt to environments where different cultures are synthesized, approach differences with tolerance, and conduct lessons with students from different nationalities are among the characteristics teachers should have. In the literature, the results of the studies on this subject reveal that teachers are the most important stakeholders for the education of refugee children and they should be supported educationally (Erdem, 2017; Madziva \& Thondhlana, 2017; Sims et al., 2002). While training teachers at universities in Turkey, it is impossible to achieve success in terms of tolerance of teacher candidates to different cultures. Studies conducted with education faculty students in Turkey have shown that teacher candidates do not positively favour Syrian refugees (Topkaya \& Akdağ, 2016). The fact that teacher candidates do not exhibit a positive attitude can indicate that refugee students may face more problems in their educational processes in the following years. Gay (2002) emphasized in his study that it is essential for teachers who will attend the classes of students with different cultures and structures to have the ability to plan their learning situations and environments.

According to the findings of this study the language barrier and the negative attitudes of peers and peer families are also effective in the adaptation problems of Syrian refugee students. It was concluded from the teachers that their friends stated that they had a prejudiced and exclusionary attitude towards refugee students at first. However, due to the efforts of experienced teachers to develop positive attitudes among students, the exclusionary attitude turned into positive attitudes over time. Cirıt Karaağaç and Güvenç (2019) reached parallel results with this study. Refugee students have difficulty adapting due to language, culture, and psychological factors; however, teachers make an effort to develop good relations between students (Kultas, 2017).

The teachers participating in the research stated that Syrian refugee students are more successful in mathematics lessons than other lessons. As a reason for this, they stated that mathematics is a universal language. However, mathematics teachers, who did not find the textbooks they used appropriately in terms of content and culture, complained about the lack of a choice of books. On the other hand, they stated that they were teaching by sticking to the textbooks. The findings of Kardeş and Akman (2019) support these results and emphasize that although teachers in Turkey usually teach with textbooks prepared for Turkish students, they are not satisfied with these resources. Likewise, Syrian refugee students participating in the research stated 
that the sourcebooks used in mathematics education are not suitable for them - the lack of a dictionary of mathematical terms as a problem.

The research results reveal that the teachers do not consider the basic mathematics knowledge of Syrian students sufficient and that the course hours are insufficient. It was stated that a small number of students had sufficient prior knowledge of mathematics. Similarly, Cırıt Karaağaç and Güvenç (2019) reveal that teachers see the academic entry characteristics of Syrian students as insufficient. It is thought that this situation may be due to the way followed in determining the grade levels of the students.

According to the study results, it was determined that mathematics teachers were confused about measurement and evaluation and tried to produce solutions in their way. Erdem (2017) also emphasized that teachers in Turkey should be trained in measurement and evaluation. It was understood that the mathematics teachers who participated in the study took multiple-choice exams generally. These results are in parallel with the results of Başaran Demir (2020). It has been concluded that multiple-choice tests are preferred rather than traditional methods in providing the student with the opportunity to get high grades with luck success.

\section{Suggestions}

Integration of Syrian students into Turkish public schools has many advantages that allow students to integrate into Turkish society and continue their education at Turkish universities and institutes.

1. Additional language education support should be provided to Syrian refugee students.

2. Psychological support should be given to Syrian refugee students fleeing the war and migrating.

3. Educational programs in schools where Syrian refugee students continue their education should be arranged according to student needs.

4. A glossary of terms should be prepared for refugee students to make mathematics education more efficient.

5. Legislation and harmonization programs should be planned and implemented for Syrian refugee students.

6. A lesson for refugees should be included in teacher training programs, and supplementary training should be offered to existing teachers.

7. In this research, detailed interviews were conducted, and the data obtained were analysed. It can be recommended to conduct research carried out by observing to allow more reliable data to be obtained. In addition, similar studies can be carried out with refugee students in other provinces of Turkey and the teachers who teach these students. Joint studies such as congresses, workshops, symposiums related to the subject can be planned.

Finally, the refugee students who can overcome the language problem can be very successful. They are also prone to speaking our language due to our neighbourhood going on for centuries.

\section{Compliance with Ethical Standards}

\section{Conflict of interest}

The authors have no relevant financial or non-financial interests to disclose.

\section{Ethical approval}

The study was carried out with the approval of the Social and Human Sciences Research Ethics Committee of Karabuk University, numbered 2021/06-24. 


\section{Author contribution}

C. İ. K. Conceptualization, Methodology, Writing - original draft, Writing - Review \& Editing, Investigation. M. M. A. Investigation, Writing - Original Draft. All authors read and approved the final manuscript.

\section{References}

Ayyıldız, M. (2011). The education of Turkish language and literature in Syria: Turkish education in three mother languages, three different ethnical structures and three different cultural complement enviroments. Abant İzzet Baysal Üniversitesi Eğitim Fakültesi Dergisi, 11(1), 11-18. https://dergipark.org.tr/en/download/article-file/16829

Başaran Demir S. (2020). Suriyeli mülteci öğrencilerin öğretmeni olmak: öğretmenlerin okul deneyimleri. Eğitim ve Bilim, 46(206), 331-354. Doi: 10.15390/EB.2020.9182

Çiçekli, B. (2009). Uluslararası hukukta mülteciler ve sı̆̆ınmacılar. Seçkin Hukuk Kitapları.

Cirıt Karaağaç, F., \& Güvenç, H. (2019). Resmi ilkokullara devam eden Suriyeli mülteci öğrencilerin eğitim sorunları. OPUS Uluslararası Toplum Araştırmaları Dergisi, 11(18), 530-568. Doi: 10.26466/opus.530733

Coşkun, İ., \& Emin M. N. (2016). Türkiye'deki Suriyelilerin eğitiminde yol haritası firsatlar ve zorluklar (SETA Yayınları 69). Turkuvaz Matbaacılık Yayıncılık A.Ş. http://file.setav.org/Files/Pdf/20160906135243 turkiyedekisuriyelilerin-egitiminde-yolharitasi-pdf.

Erdem, C. (2017). Sınıfında mülteci öğrenci bulunan sınıf öğretmenlerinin yaşadıkları öğretimsel sorunlar ve çözüme dair önerileri. Medeniyet Ĕ̈itim Araştırmaları Dergisi, 1(1), 26-42. https://dergipark.org.tr/tr/pub/mead/issue/30039/322019

Erden, O. (2013, May 11-13). Experiences of a Syrian family in social and educational context: Case study [Oral presentation]. International Conference on Gender and Migration: Critical Issues and Policy Implications, Istanbul, Turkey. https://drive.google.com/file/d/1ZOzwp5f2YdM3CRY4kDYnEESdo8EDjTVO/view

Feuerherm, E. (2013). Language policies, identities, and education in refugee resettlement. (Publication No. 3602059) [Doctoral dissertation thesis, University of California]. ProQuest Dissertations and Theses Global.

Gay, G. (2002). Preparing for culturally responsive teaching. Journal of Teacher Education, 53, 106-116. Doi: $10.1177 / 0022487102053002003$

Gencer, T. E. (2017). Göç ve eğitim ilişkisi üzerine bir değerlendirme: Suriyeli çocukların eğitim gereksinimi ve okullaşma süreçlerinde karş1laştıkları güçlükler. Journal of International Social Research, 10(54), 838-851. Doi: 10.17719/jisr.20175434652

İnci Kuzu, Ç. (2021). Aile ve öğretmen yaklaşimlarinin matematik kaygi düzeyine etkisi ile ilgili öğrenci görüşleri. Ekev Akademi Dergisi, 25(85), 113-128. http://www.ekevakademi.org/Makaleler/1853949199_07\%20Cigdem\%20INCI\%20KUZU.pdf

Jafari, K. K., Tonğa, N., \& Kışla, H. (2018). Suriyeli öğrencilerin bulunduğu sınıflarda görev yapan sınıf öğretmenlerinin görüşleri ve uygulamalar1. Academy Journal of Educational Sciences, 2(2), 134-146. Doi: 10.31805/acjes.479232

Kardeş, S., \& Akman, B. (2019). Suriyeli mültecilerin eğitimine yönelik öğretmen görüşleri. İlköğretim Online, 17(3), 1124-1237. Doi: 10.17051/ilkonline.2018.466333

Kaştan, Y. (2015). Türkiye'de göç yaşamiş çocuklarin eğitim sürecinde karşilaşilan problemler. Uluslararası Sosyal ve Eğitim Bilimleri Dergisi, 2(4), 216-229. https://dergipark.org.tr/tr/pub/ijoses/issue/8549/614109

Kayacık, B. E. (2020). Suriyeli öğrencilerin ĕğitimine yönelik öğretmen görüşleri. Pamukkale Üniversitesi. http://acikerisim.pau.edu.tr:8080/xmlui/bitstream/handle/11499/35155/Baha\%20Erdem\%20KAYACIK.pdf?sequence=1\&isAllowed

=y

Kultas, E. (2017). Türkiye'de bulunan eğitim çağındaki Suriyeli mültecilerin eğitimi sorunu (Van İli örneği) (Publication No. 480164) [Master's thesis, Yüzüncü Yıl Üniversitesi]. Yükseköğretim Kurulu Başkanlığı Tez Merkezi. 
Madziva, R., \& Thondhlana, J. (2017). Provision of qualityeducation in thecontext of Syrian refugee children in the UK: Opportunities and challenges. Compare: A Journal of Comparativeand International Education, 47(6), 942-961. Doi: $10.1080 / 03057925.2017 .1375848$

Miller, J. (2009). Teacher identity. In A. B. Jack \& C. Richards (Eds.), The Cambridge guide to second language teacher education (pp. 172-181). Cambridge University Press.

Ministry of Interior Migration Administration (2020). Geçici Korumamız Altındaki Suriyeliler. https://www.goc.gov.tr/gecicikorumamiz-altindaki-suriyeliler

Özdemir, E. (2017). Suriyeli mülteciler krizinin Türkiye’ye etkileri. Uluslararası Kriz ve Siyaset Araştırmaları Dergisi, 1(3), $114-140$. https://dergipark.org.tr/tr/pub/uksad/issue/33359/371266

Özyıldırım Gümüş, F., Acar T., \& Yetkin Özdemir, E. (2015). Ortaokul öğrencilerinin gözünden matematik öğretmenleri. Mehmet Akif Ersoy Üniversitesi Eğitim Fakültesi Dergisi, 1(34), 23-51. https://dergipark.org.tr/tr/pub/maeuefd/issue/19407/206306

Patton, M. Q. (1990). Qualitative evaluation and research methods (2nd ed.). Sage Publications, Inc.

Perşembe, E. (2010). F. Almanya'nın Baden-Württemberg Eyaletinde eğitim sistemi ve Türk göçmen çocuklarının eğitim sorunları. Ondokuz Mayıs Üniversitesi İlahiyat Fakültesi Dergisi, 29(29), 55-80. https://dergipark.org.tr/tr/pub/omuifd/issue/20292/215382

Roxas, K. (2010). Who really wants "the tired, the poor, and the huddled masses" anyway?: Teachers' use of cultural scripts with refugee students in public schools. Multicultural Perspectives, 12(2), 65-73. Doi: 10.1080/15210960.2010.481180

Sims, M., Hayden, J., Palmer, G., \& Hutchins, T. (2002). Young children who have experienced refugee or warrelated trauma. European Early Childhood Education Research Journal, 10(1), 99-110. Doi: 10.1080/13502930285208871

Topkaya, Y., \& Akdağ, H. (2016). Sosyal bilgiler öğretmen adaylarının Suriyeli sığınmacılar hakkındaki görüşleri (Kilis 7 Aralık Üniversitesi örneği). Çankırı Karatekin Üniversitesi Sosyal Bilimler Enstitüsü Dergisi, 7(1), 767-786. https://dergipark.org.tr/tr/pub/jiss/issue/25889/272782

Tuncay, A. A. (2021). Ana dili Türkçe olmayan mülteci çocuklarda kelime tanıma envanterinin kullanımı. Ana Dili Eğitimi Dergisi, 9(1), 59-75. Doi: 10.16916/aded.804297

Turkish Language Society (2021) https://sozluk.gov.tr/

Watkins, K., \& Zyck, S. A. (2014). Living on hope, hoping for education - The Failed Response to the Syrian Refugee Crisis. Overseas Development Institute. https://cdn.odi.org/media/documents/9169.pdf

Yıldırım, A., \& Şimşek, H. (2013). Sosyal bilimlerd nitel araştırma yöntemleri (9. Baskı). Seçkin Yayıncılık 